\title{
平成24年7月豪雨を対象にした 山国川流域の分布型流出・洪水汇濫解析 \\ NUMERICAL SIMULATION OF RAINFALL-RUNOFF AND FLOOD INUNDATION FLOWS IN THE YAMAKUNI RIVER BASIN AT KYUSHU-HOKUBU HEAVY RAIN IN 2014
}

\author{
重枝末玲 ${ }^{1} \cdot$ 秋山壽一郎 $^{2} \cdot$ 松本拓磨 $^{3} \cdot$ 山本峻平 $^{3} \cdot$ 川上優 ${ }^{4}$ \\ Mirei SHIGE-EDA, Juichiro AKIYAMA, Takuma MATSUMOTO, \\ Shunpei YAMAMOTO and Yu KAWAKAMI \\ 1正会員 博士(工) 九州工業大学大学院准教授 工学研究院建設社会工学研究系 \\ ( (804-8550 北九州市戸畑区仙水町1-1) \\ 2 フェロー会員 Ph.D. 九州工業大学大学院教授 工学研究院建設社会工学研究系 (同上) \\ 3学生会員 九州工業大学大学院 工学府建設社会工学専攻博士前期課程（同上） \\ 4学生会員 九州工業大学 工学部建設社会工学科（同上）
}

\begin{abstract}
Numerical simulations of flooding event in the Yamakuni river basin at Kyushu-hokubu heavy rain in 2014 was performed by a numerical model for rainfall-runoff in watershed and flood inundation flows. The rain-fall runoff was simulated by a distributed hydrological model. The flood flow in rivers and inundation flows on the ground were simulated simultaneously by the $2 \mathrm{D}$ free-surface flow model. The simulated results compared with the observed discharge into the Yabakei dam, water level of flood marker and maximum inundation area. It shows that the model has ability to reproduce runoff, flooding and inundation process, but the more improvement is needed to predict the runoff, flooding and inundation process with reasonable accuracy.
\end{abstract}

Key Words : Yamakuni river, Kyushu-hokubu heavy rain 2014, rainfall-runoff, flood flow, inundation flow, numerical simulation

\section{1.はじめに}

平成24年7月3日および13〜14日にかけて，本州付近に 停滞した梅雨前線に暖かく湿った空気が流れ込み，九州 北部で豪雨となった。 この豪雨により，九州北部の5水 系7河川が汇濫し，福岡，大分，熊本県で総被害額が 1700億円1になるなど，甚大な被害が生じた。

近年の水害の特徵は，短時間に集中した豪雨に起因す る点にあり，気象庁では「これまでに経験したことのな いような大雨」のような表現を用いるほど，雨の降り方 が変化している. 今後の防災・減災対策を講じる上で, このような短時間集中豪雨に対して，複数のシナリオを 用意し，流域からの流出プロセスやその結果によって生 じる河道での洪水・汇濫原での汇濫プロセスなどの雨水 の挙動を事前に把握することはますます重要になると考 えられる.

降雨外力からの流出, 洪水, 汇濫の一連のプロセスを 予測するツールとして，「統合型降雨流出・洪水汇濫モ
デル」22,3,4,4,5)が存在する.これに加え，近年では降雨流 出から氾濫までの一連のプロセスを流域全体で取り扱う ことが可能な数值モデルまでも開発されつつある6,7). 著 者らは, 降雨外力から流出, 洪水, 汇濫の一連のプロセ スを予測できる「流域流出・都市域氾濫解析モデル」8) を開発し，同モデルが流域の雨水の挙動，河道での洪水 流の挙動, 都市域での詳細な汇濫流の挙動を予測可能で ある8ことを示している.

本研究は，以上のような背景を踏まえ，九州北部豪雨 災害で7月3日と13 14日の2度にわたり甚大な被害が生じ た山国川流域を対象に，著者らの開発した「流域流出・ 都市域氾濫解析モデル」を用いた流出・洪水汇濫解析の 再現性を検討したものである。 まず，山国川流域の耶馬 渓ダム流域を対象とした分布型流出解析パラメータの推 定と，空間分布の異なる二つの降雨がパラメータに及ぼ す影響について検討する. 次に, 推定されたパラメータ を用いて，山国川流域を対象に分布型流出・洪水汇濫解 析を行い，その再現性を検討寸る. 最後に，これらを踏 


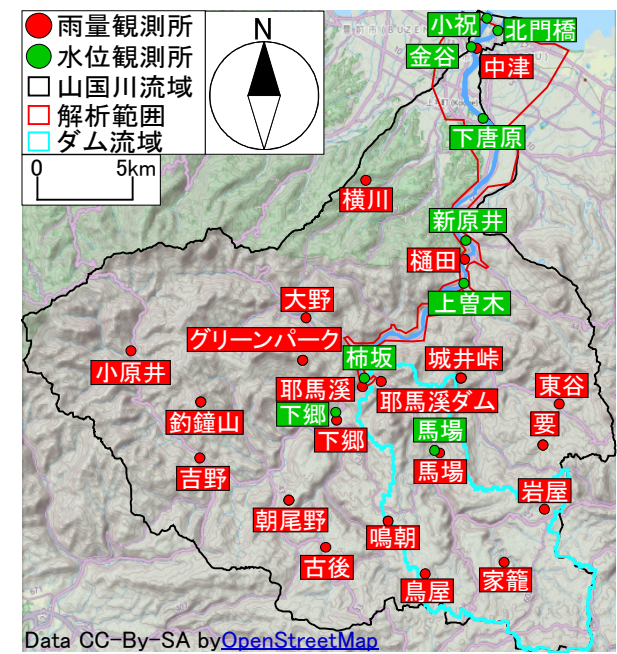

図-1 山国川流域の概要
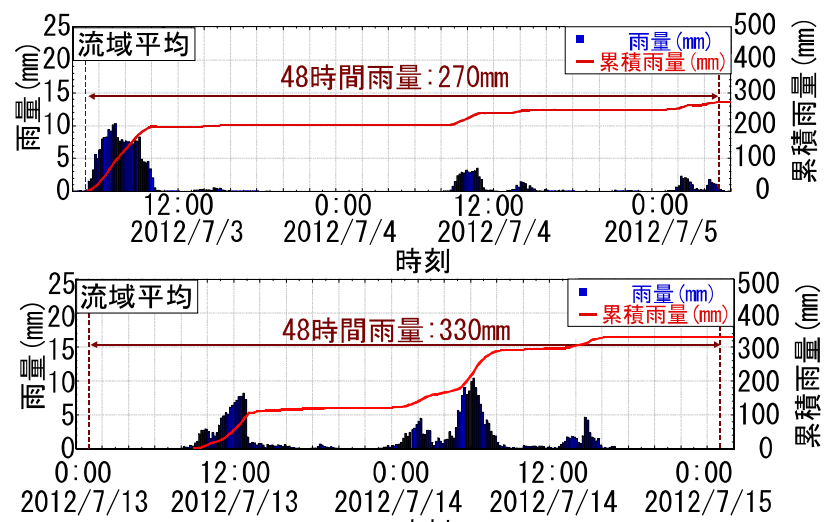
時刻

図-2 流域平均降雨ハイエトグラフ(上 : 7月3日豪雨, 下 : 7月13 ～14日豪雨）

まえ，同モデルの今後の改善点について検討する.

\section{2. 山国川流域と平成24年7月豪雨時の被災状況の 概要}

（1）山国川と流域の概要9)

山国川流域は福岡県と大分県の県境に位置しており, その流域面積は $540 \mathrm{~km}^{2}$ ，土地利用は山地が約 $91 \%$ ，農地 が約 $7 \%$, 市街地が約 $2 \%$ 占めている. 山国川は，幹 川流路延長 $56 \mathrm{~km}$ の一級河川であり，河床勾配は上中流 で1/200以上，下流部で $1 / 500 \sim 1 / 1,000$ 程度の急流河川で ある. 図-1に山国川流域の概要，雨量・水位観測所を示 す.なお，図の背景にはOpenStreetMap ${ }^{10)}$ の数值地図を 用いた。

\section{(2) 7月3日豪雨と7月13〜14日豪雨の概要}

7月3日の豪雨では，山国川流域の9つの雨量観測所(下 郷, 耶馬溪ダム, 東谷, 馬場, 岩屋, 家籠，鳥屋，古後， 吉野)で観測史上最大の3時間雨量を記録し，その中でも 下郷雨量観測所では 1 時間雨量についても観測史上最大 73mmを記録した。図-2は，7月3日および7月13 14日豪 雨時の流域平均の降雨ハイエトグラフを示したものであ る。これより，(1) 7月3日の豪雨では一山波形で200mm

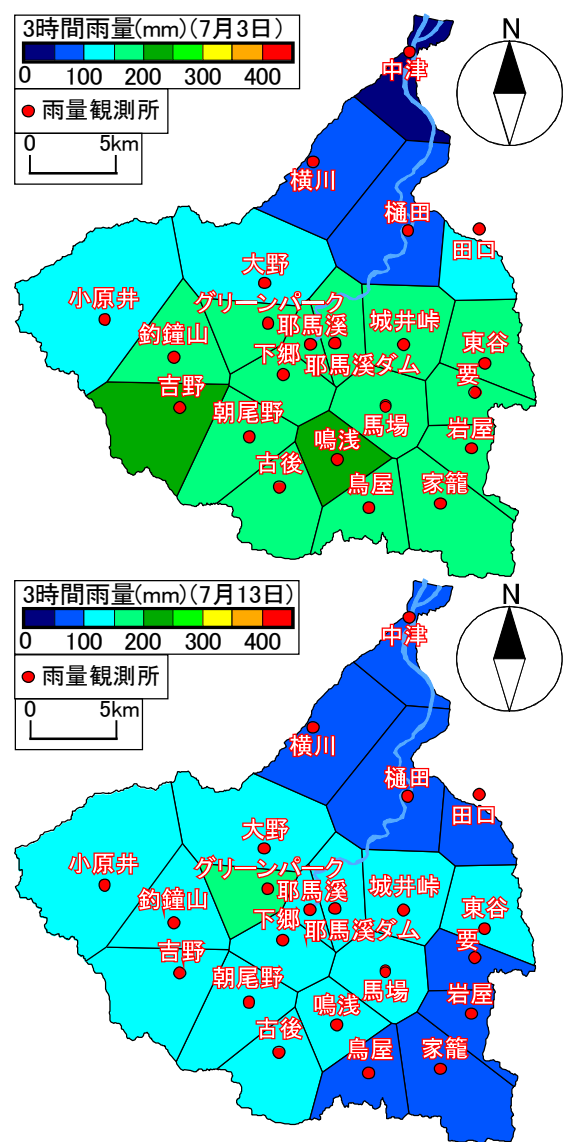

図-3 3時間雨量の空間分布(上 : 7月3日豪雨, 下 : 7月13 14 日豪雨)

程度の累加雨量があること，(2) 7月13 14日豪雨では二 山波形で各波形の累加雨量は $100 \mathrm{~mm}$ と $200 \mathrm{~mm}$ 程度であ ること，などがわかる．各豪雨の計画降雨継続時間での 雨量の確率規模は，それぞれ7月3日豪雨は $1 / 17 ， 7$ 月 13 〜14日は1/62であった．図-3は，7月3日および13 14日 豪雨の3時間雨量の空間分布を示したものである. これ より，(1) 7月3日の豪雨では流域の南東側に，(2) 7月 13 14日豪雨では流域の南西側に降雨が集中しているこ と，などがわかる．このように，今回の豪雨は波形や空 間分布に違いはあるが，その特徴は短時間集中豪雨であ ることが確認された.

\section{（3）出水状況と被害の概要}

7月3日の出水では，国土交通省管理の金谷，新原井， 上曽木，柿坂，下郷の5箇所の水位観測所で，7月 13 14 日の出水では, 柿坂, 下鄉の2箇所の水位観測所で既往 最高水位を更新した. 図-4は, 両出水での被害状況の概 要を示したものである. 7月14日時点の調査では，7月3 の出水で浸水面積58.1ha，浸水家屋数 194 戸(床上浸水： 132戸，床下浸水：62戸)，7月13，14日の出水で浸水面 積41.0(ha), 浸水家屋数187戸(床上浸水：124戸，床下浸 水：63戸)の浸水被害が，河川管理施設では主に護岸崩 落などの被害が7月3日の出水で17ケ所，7月13 14日の出 水で4ヶ所生じた. 


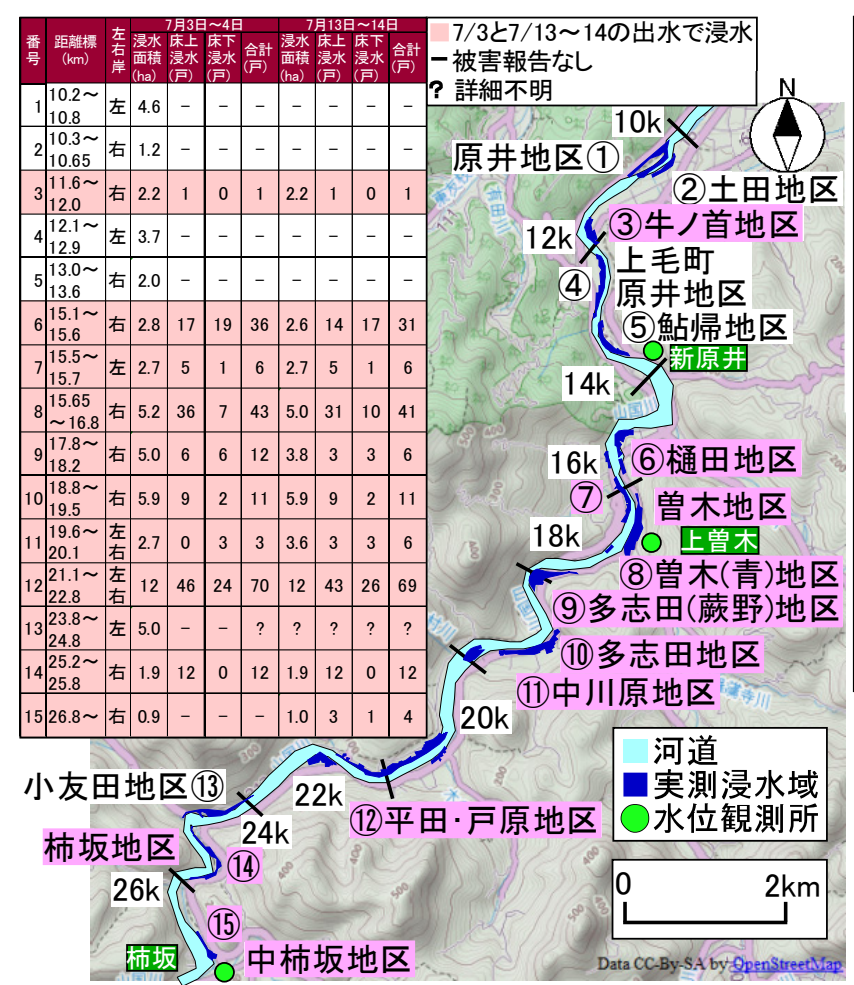

図-4 浸水被害と河川管理施設の被災状況(左

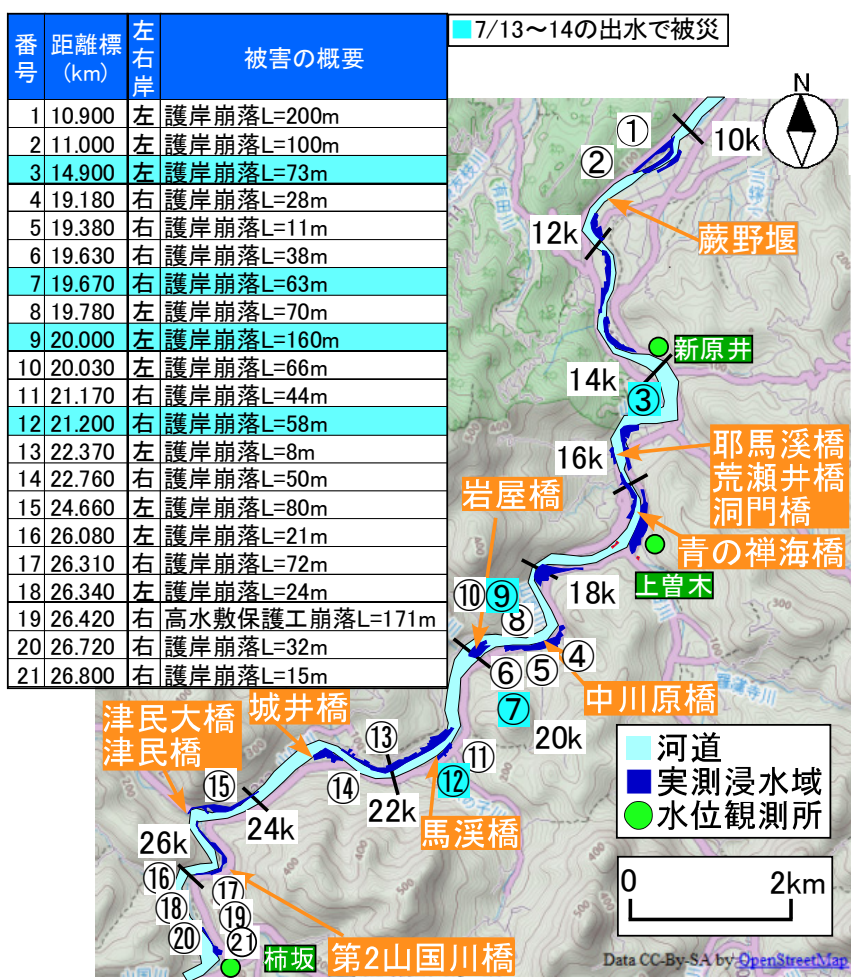

浸水箇所，右 : 護岸等の被災箇所)

\section{3. 解析の概要}

\section{（1）流域流出・都市域汇濫解析モデルの概要}

洪水汇濫解析には，「流域流出・都市域汇濫解析モデ ル」8）を用いた.「流域流出・都市域汇濫解析モデル」 ${ }^{8)}$ は，(1)セル分布型流出解析モデル11)，(2)平面2次元洪水 追跡モデル11)，(3)都市域汇濫解析モデル12)の3つのモデル で構成され，それぞれの結果を境界条件あるいは内部境 界条件で接続することで，任意の降雨外力から，流域で の雨水の挙動を把握した上で, 精度の高い本川の洪水追 跡を介して, 都市域での詳細な浸水プロセスの予測を行 うモデルである. モデル(1)にはkinematic waveモデル8)を, (2)と(3)のモデルには非構造格子，有限体積法，流束差分 離法に基づく平面2次元不定流モデル8)を用いている．モ デル(1)(3)の詳細については参考文献》に示寸通りである.

\section{（2）解析条件}

解析は平成24年7月3日の豪雨を対象に行った. 分布型 流出解析の対象領域は山国川流域, 平面2次元洪水追跡 の対象領域は山国川とその支川の中津川，汇濫解析の対 象領域は, 平面2次元洪水追跡で対象とする山国川と中 津川を除く, 図-1中の赤枠で示寸領域とした. 降雨外力 には，図-1に示寸各雨量観測所での実績降雨を与えた.

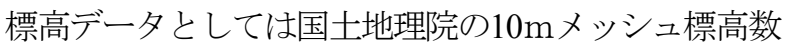
值モデル13)を，土地利用データとしては国土政策局の

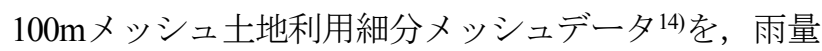
データとしては国土交通省水文水質データベースから得 られる実測データ15)を，河道形状および河床高のデータ としては各距離標の距離標座標と横断面図16を, 粗度係
数としては計画粗度係数16を用いた，標高，土地利用 データ, 落水線等の作成したデータの一例を図-5に示寸.

解析対象期間は, 2012年7月 3日6:00〜 4日 14:00 とし, 洪水汇濫解析の下流端境界条件には, 山国川の小祝観測 所, 中津川の北門橋観測所で得られた実測の水位八イドロ グラフを与えた.

分布型流出解析のモデルパラメータは, 後述する検討 に基づき，土地利用に応じて表-1の值を与えた．ここに， 等価粗度係数 $N\left(\mathrm{~m}^{-1 / 3} \cdot \mathrm{s}\right)$, 土層厚 $d_{\mathrm{c}}, d_{\mathrm{s}}$, 飽和透水係数 $k_{\mathrm{a}}$, 透 水係数比 $\beta$ である.

\section{4. 山国川流域の耶馬渓ダム流域を対象とした分 布型流出解析パラメータの推定}

山国川では7月3日，7月13〜14日のいずれの出水時に も，水位計の破損による久測データが多数あるため，河 川水位に基づく分布型流出解析のモデルパラメータの推 定 ${ }^{17)}$ を行うことが困難であった．そのため，ここでは耶 馬溪ダムへの流入流量に基づき, 分布型流出解析モデル のモデルパラメータの推定を行った.

耶馬渓ダムは図-1に示すように，山国川と山移川の合 流地点上流に位置しており, その流域は図-1中の水色の

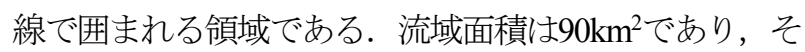
の土地利用は森林が約 $90 \%$, 田が約 $1 \%$, 農地が約 $1 \%$, 都市が約 $0.2 \%$ ，荒地が約 $1 \%$ ，水域が約 $5 \%$ である.

まず，パラメータが流出流量に及ぼす影響を調べる目 的で実験計画法18)を用いた. 実験計画法は，複数のモデ ルパラメータが目的関数に及ぼす影響を把握することを 目的とした解析条件設定のための統計的な手法であり, 


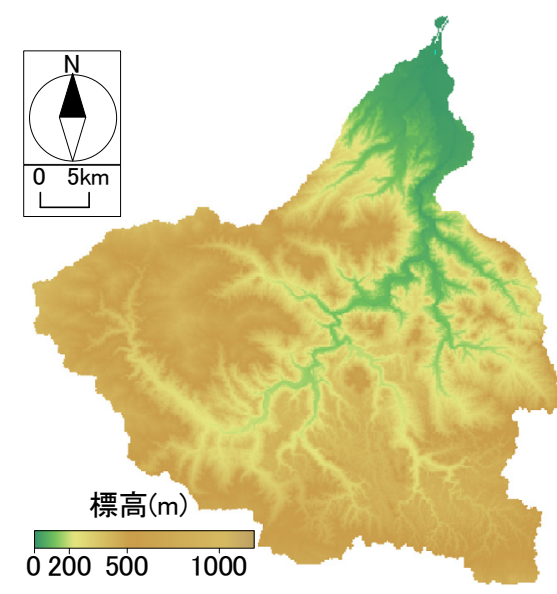

(a) 標高

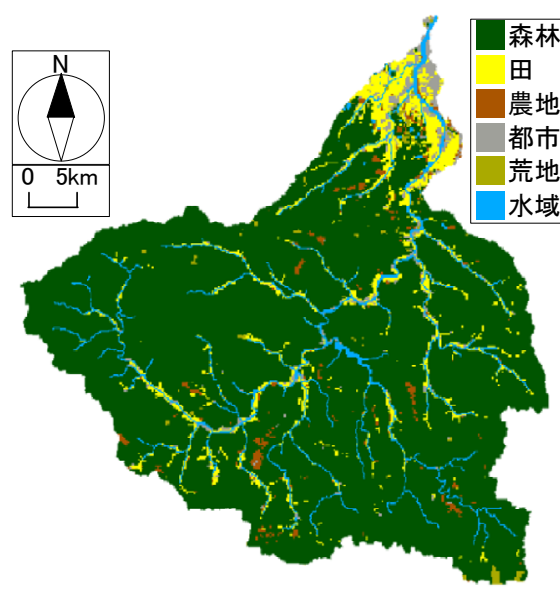

(b) 土地利用

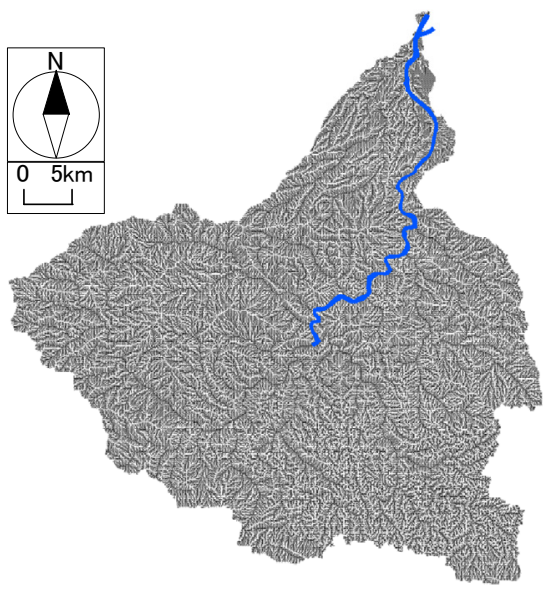

(c) 落水線

図-5 解析データの一例

表-1 分布型流出解析に用いたパラメータ値(左 : 7月3日豪雨, 右 : 7月13〜14日豪雨)

\begin{tabular}{|c|c|c|c|c|c|}
\hline \multicolumn{2}{|c|}{$\mathrm{N}\left(\mathrm{m}^{-1 / 3} \cdot \mathrm{s}\right)$} & $\mathrm{k}_{\mathrm{a}}(\mathrm{m} / \mathrm{s})$ & $\mathrm{d}_{\mathrm{c}}(\mathrm{m})$ & $\mathrm{d}_{\mathrm{s}}(\mathrm{m})$ & $\beta$ \\
\hline 森林 & 0.70 & 0.01 & 0.05 & 0.015 & 6 \\
\hline 田 & 2.0 & & & & \\
\cline { 1 - 2 } 農地 & 0.30 & & & & \\
\cline { 1 - 2 } 都市 & 0.055 & - & - & - & - \\
\cline { 1 - 2 } 荒地 & 0.3 & & & & \\
\cline { 1 - 2 } 水域 & 0.045 & & & & \\
\hline
\end{tabular}

\begin{tabular}{|c|c|c|c|c|c|}
\hline \multicolumn{2}{|c|}{$\mathrm{N}\left(\mathrm{m}^{-1 / 3} \cdot \mathrm{s}\right)$} & $\mathrm{k}_{\mathrm{a}}(\mathrm{m} / \mathrm{s})$ & $\mathrm{d}_{\mathrm{c}}(\mathrm{m})$ & $\mathrm{d}_{\mathrm{s}}(\mathrm{m})$ & $\beta$ \\
\hline 森林 & 0.70 & 0.01 & 0.045 & 0.05 & 6 \\
\hline 田 & 2.0 & & & & \\
\cline { 1 - 2 } 農地 & 0.30 & & & & \\
\cline { 1 - 2 } 都市 & 0.055 & - & - & - & - \\
\cline { 1 - 2 } 荒地 & 0.3 & & & & \\
\cline { 1 - 2 } 水域 & 0.045 & & & & \\
\hline
\end{tabular}
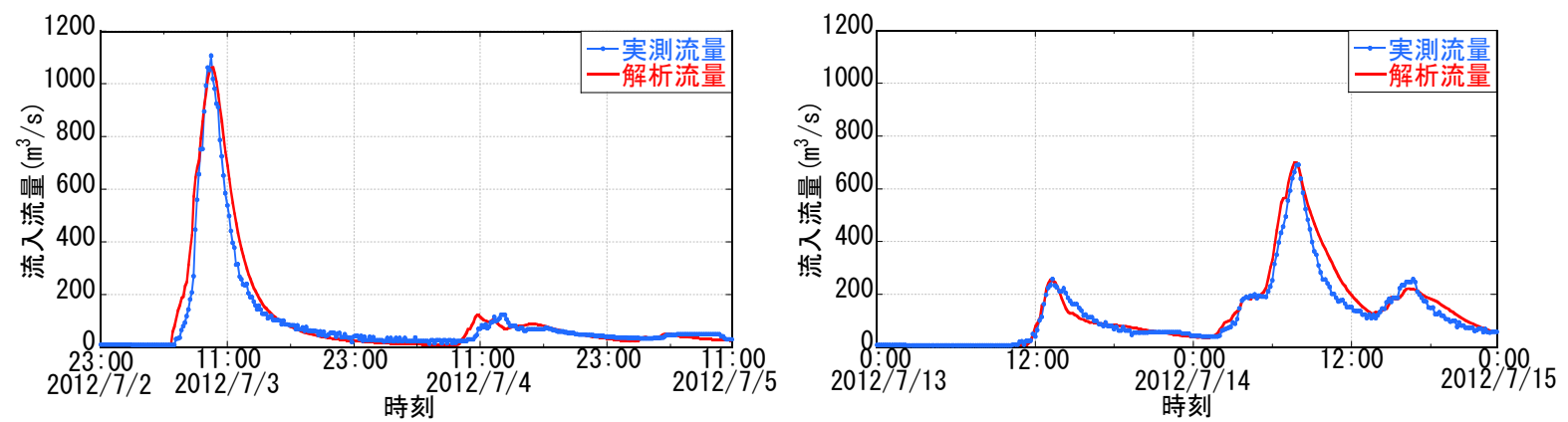

図-6 耶馬溪ダム流入流量の実測値と解析結果との比較(左 : 7月3日豪雨，右 : 7月13 14日豪雨)

同手法を用いることで，各モデルパラメータが目的関数 に及ぼす影響を評価できる効率的なパラメータの組み合 わせを設定することができる. 目的関数には平均2乗誤 差を用いた。耶馬溪ダム流域の土地利用の $90 \%$ は森林で あるため, パラメータの推定は森林と水域に対して行っ た. 他のパラメータ值については, 標準值の平均值を用 いた. 実験計画法に基づき60通りの解析条件を設定した.

これらの結果に基づき，以下のようにパラメータの推 定を行った。まず，7月3日の豪雨に対して実測值を再現 できるようなパラメータを推定した．7月13 14日の豪雨 については, 両出水は短い期間で発生したため, 地表面 の土地利用や土畩の状態は変化しないと考え, 7月3日の出 水に対して推定した地表面の粗度 $N$, 土壤中の流れに関 する飽和透水係数 $k_{\mathrm{a}}$, 透水係数比 $\beta$ 值を用い, 土壌中の流 れに関する土層厚 $d_{\mathrm{c}}, d_{\mathrm{s}}$ についてのみ推定した.

表-1は，7月3日及び13〜14日豪雨時のパラメータの推 定值を示す。図-6は，7月3日及び13，14日豪雨時の耶馬 溪ダム流入流量について, 実測值と最適パラメータ值の 解析結果を示したものである.これより，本解析結果は，
ピーク流量には約 $2.5 \%$ の誤差が生じるが，増水時，減 水時の流量, 波形ともに再現性が高いことが確認できる. ただし，7月13 14日豪雨については減水期の流量ハイド ログラフの再現性が十分でないことから，土層厚のパラ メータの最適化が十分ではない可能性がある。 なお，本 解析結果のNash効率は0.93 0.94であった.

7月3日と7月13 14日豪雨の土層厚 $d_{\mathrm{c}}, d_{\mathrm{s}}$ 值を比較する と，7月3日の流出パラメータは7月13 14日降雨に比べ, 土層厚のパラメータが小さいことが確認できる.これは, 7月3日豪雨では耶馬溪ダム流域に集中した豪雨であるた め, 雨水は早期に表面流として流域から流出し, ダムへ 流入したためと考えられる.

\section{5. 流域流出 - 都市域氾濫解析の結果と考察}

図一7は, 流域流出・都市域汇濫解析より得られた最大 水位の縦断変化と痕跡水位との比較を行なったものであ る. これより, 最大水位の解析結果は, (1) 距離標 $19 \mathrm{~km}$ より上流側については, 痕跡水位を上回ること, (2) 距 


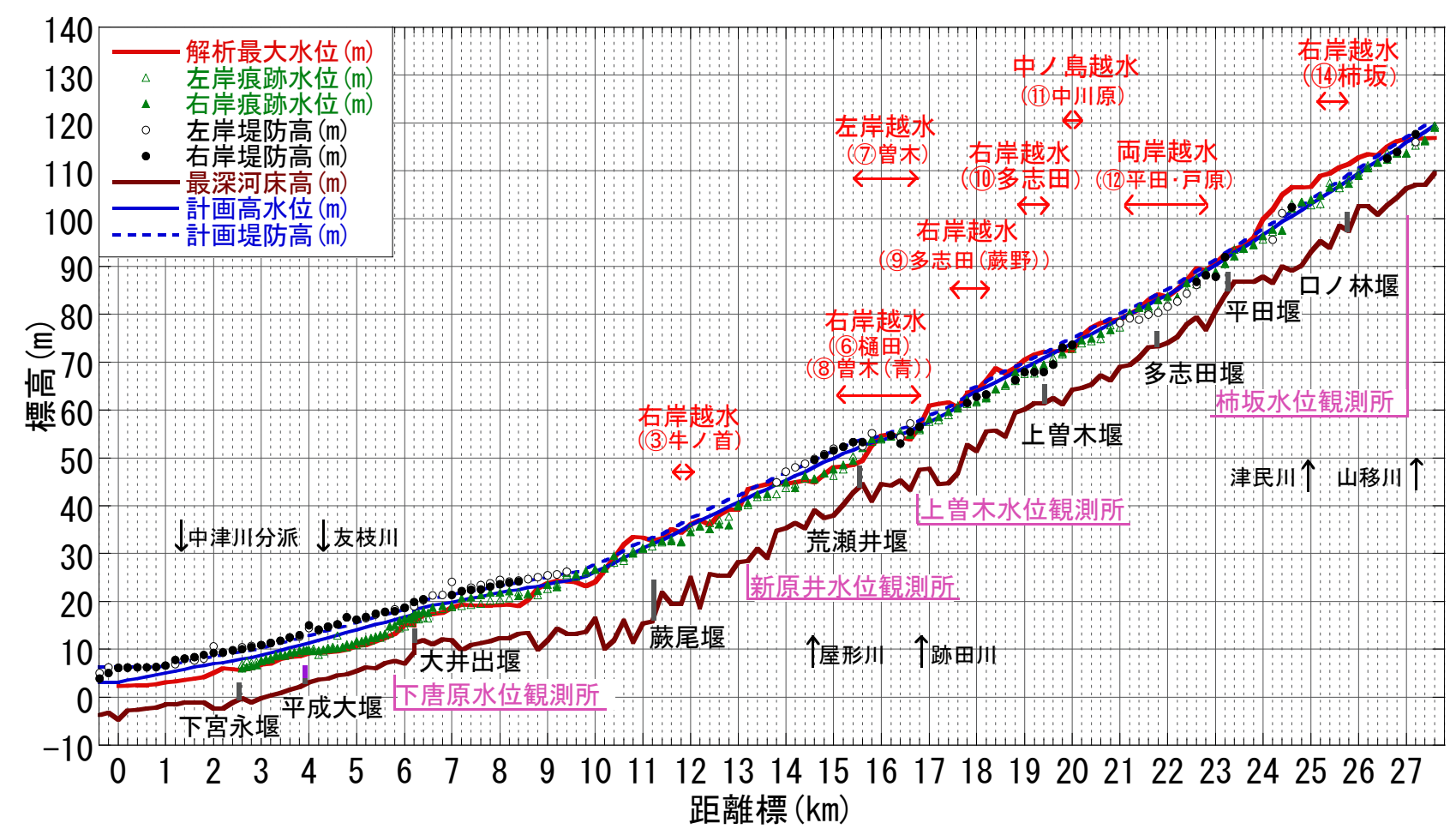

図-7 解析結果の最大水位と痕跡水位との比較(7月3日豪雨)

離標 $17 \mathrm{~km} \sim 19 \mathrm{~km} の$ 上曽木水位観測所上流周辺も同様に, 痕跡水位を上回ること，(3) 距離標14 17kmでは痕跡水 位をある程度再現していること，(4) 距離標 $11.2 \mathrm{~km}$ の蕨 尾堰周辺より上流では痕跡水位を上回ること，(5) 距離

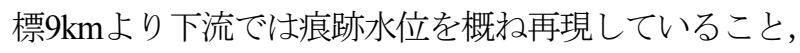
などが確認できる.

図-8は，流域流出・都市域氾濫解析より得られた最大 浸水域と実績浸水域との比較を行なったものである。こ れより, 解析結果は, (1) 距離標 $19 \mathrm{~km}$ より流側では, 実績浸水域を概ね再現していること，一方，(2) 距離標 17 19km地点の上曽木観測所の上流付近で浸水域を過大

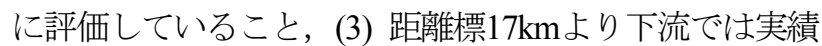
浸水域を概小再現していること，などが確認できる。 な お，距離標 $20 \mathrm{~km}$ 周辺の浸水は中の島での浸水である.

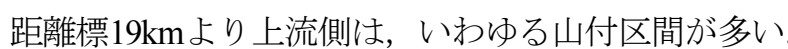
そのため，解析結果は，痕跡水位を過大に評価している にも関わらず，浸水域は実績と概ね一致している．解析 結果が，距離標 $19 \mathrm{~km}$ より流側で痕跡水位を上回った

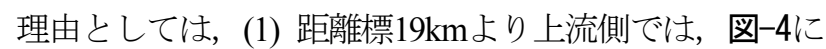
示すように，広範囲にわたり護岸崩落等が生じており， 河道横断面形状が大きく変化していること，(2) 同豪雨 災害時には本研究の洪水追跡と汇濫解析の対象領域より も上流側で汇濫が生じているため，分布型流出解析によ り算出した河道上流端の流入流量が，汇濫流量分を含ん でいるため過大に評価されたこと，などが考えられる.

距離標 $17 \mathrm{~km} \sim 19 \mathrm{~km}$ 周辺では，解析水位は痕跡水位を 上回っており，解析浸水域も実績に比べ過大に評価して いる．これは，上述の過大に評価した流量が，この区間 で汇監したために浸水域は過大に評価されたと考えられ
る. 下流側の距離標14 17kmで，解析結果が痕跡水位を 概ね再現していることを踏まえると，汇濫によって下流 の流量が減少し, 流量が実績に近いものになったと考え られる。実際，山国川の計画基準点の下唐原では，平成 24年7月 3 日の出水の実績流量は約 $4,000 \mathrm{~m}^{3} / \mathrm{s}$ であった 19$)$ が，解析から得られたピーク流量も約 $4,000 \mathrm{~m}^{3} / \mathrm{s}$ であり， この流量と同程度であった.

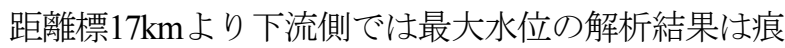
跡水位をある程度再現しており，そのため浸水域もある 程度再現している. しかし，蕨尾堰(距離標 $11.2 \mathrm{~km}$ )周辺 では再現性が低い，これは，蕨尾堰周辺では，図-4に示

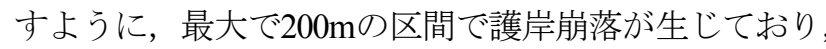
河道の横断面形状が大きく変化したためと考えられる.

以上のことから, 降雨と下流端水位を与条件とした本 解析は，(1) 山国川での痕跡水位および実績浸水域をあ る程度再現できるが，(2) 痕跡水位や浸水域を過大また は過少に評価する区間も存在することが確認された。実 績との差異が生じた理由としては，(1)流入流量の過大評 価については，流域流出解析において流域での氾濫流量 が考慮されておらず，またその影響もパラメータに含ま れていないこと，(2)水位の過大評価については大規模な 護岸崩落が生じるなど，河床や河道が大きく変動したた め，その区間での流積分を過小に評価したこと，などが 考えられる，これらのことは，河道の洪水や汇濫をより 高い精度で予測するためには，(1) 洪水と河床変動の一 体解析による河道内の水位の予測が必要なこと, (2) 流 出解析において，汇濫が河道への流出流量に及ぼす影響 を考慮した計算パラメータの設定あるいは流出解析の枠 組みでの氾監の取扱いが必要なことを示唆している. 


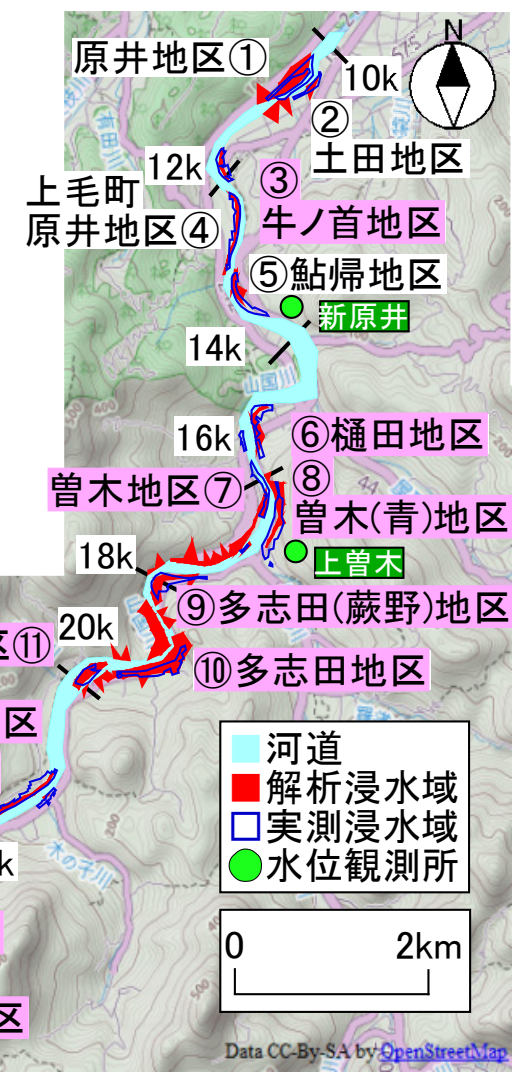

図-8 実績浸水域と洪水汇濫解析より得られた最大浸水深との 比較(7月3日)

\section{6. おわりに}

本研究では，九州北部豪雨災害で7月3日と13 14日の2 度にわたり甚大な被害が生じた山国川流域を対象に,

「流域流出・都市域汇濫解析モデル」を用いた流出・洪 水汇濫解析を行い，その再現性について検討した，その 結果，(1) 山国川流域の耶馬渓ダム流域を対象とした分 布型流出解析のパラメータを推定し, 空間分布の異なる 二つの降雨に対して，土壌に関するパラメータを変化さ せることで，ダムへの流入流量を再現できること，(2) 本モデルは, 降雨と下流端水位を与条件として, 痕跡水 位や浸水域を過大または過少に評価する区間も存在する が，山国川での痕跡水位および実績浸水域をある程度再 現できること，(3) 出水時に河道や河床が大きく変化す る急流河川では, 洪水と河床・河道変動を一体として解 析することが必要であること，(4) 流出解析の対象領域 で汇濫が生じた場合には，この影響を考慮した流出流量 の予測が必要であること, などが確認された. 今後は, 平面2次元洪水モデルに河床変動モデルを組み込むとと もに, 流出解析モデルをdiffusion waveあるいはdynamic wave モデルに変更することで，上記の(3)，(4)を取り扱 うことが可能なモデルに改善したいと考えている.

謝辞 : 本研究を実施するに当たり，山国川河川事務所の 関係各位には現地調査の実施やデータの提供など多大な 協力を得た．また，本研究を遂行するに当り，本学学部
4年生の道岡大地君には, データ整理等で協力を得た. ここに記して感謝の意を表します.

\section{参考文献}

1) 日本経済新聞社：日本経済新聞 電子版（8月15日）, 2012.

2) 辻本哲郎, 本守眞人, 安部友則, 山田哲夫 : 氾濫シミュ レーション手法の開発と東海豪雨災害の再現，河川技術論 文集，第8巻，pp.121-126，2002.

3) 戸田圭一, 井上和也, 村瀬賢, 市川 温, 横尾英男 : 豪雨 による都市域の洪水氾濫解析, 土木学会論文集, No. 633/II-53, pp.1-10, 2000.

4) 川池健司, 井上和也, 戸田圭一, 野口正人 : 低平地河川 流域での豪雨による都市汇濫解析, 土木学会論文集, No. 761/II-67, pp.57-68, 2004.

5）小林健一郎, 寶 馨, 奥勇一郎 : 統合型降雨流出 - 洪水氾 濫モデルによる佐用町洪水災害分析と経済被害推定, 水工 学論文集，第55巻，p.S_949-S_954， 2011.

6) 佐山敬洋, 建部祐哉, 藤岡奨, 牛山朋来, 萬矢敦啓, 田 中茂信：2011年夕イ洪水を対象にした緊急対応の降雨流 出氾濫予測，土木学会論文集，No.400/II-22, pp. 1-15， 2012.

7) 田中智大, 立川康人, 萬和明: 分布型流出モデルをネス ティングする流出・氾濫一体型モデルの構築, 土木学会論 文集B1(水工学)，Vol.70， No.4，pp.I_1495-I_1500，2014.

8）秋山壽一郎, 重枝未玲, 小園裕司：流域特性を考慮した 都市域汇濫解析モデルと都市域での浸水プロセスの予知, 水工学論文集, 第54巻, pp.919-924, 2010.

9）国土交通省九州地方整備局: 山国川水系河川整備計画【原 案】 - 国管理区間 -, 2008.

10) OpenStreetMap : http://openstreetmap.org/, 2014

11）重枝末玲，秋山壽一郎，小園裕司：遠賀川流域の分布型 流出解析と複数の支川を考慮した平面 2 次元洪水追跡, 河 川技術論文集，第16巻，pp.443-448，2010。

12）秋山壽一郎, 重枝未玲, 田邊武司：下水道網を考慮した 飯塚市街地の汇濫解析, 水工学論文集, 第53巻, pp.829834, 2009.

13）国土地理院 : http://www.gsi.go.jp/, 2014

14）国土政策局: http://www.mlit.go.jp/kokudoseisaku/, 2014

15) Common MP : 水文水質データ, http://framework.nilim.go.jp/, 2014.

16）国土交通省九州地方整備局山国川河川事務所： http://www.qsr.mlit.go.jp/yamakuni/, 2014.

17）重枝未玲，秋山壽一郎，野村心平：実測水位に基づく分 布型流出・平面 2 次元洪水追跡モデルのパラメータ最適化 法，河川技術論文集，第18巻，pp.459-464， 2012.

18）岩崎学: 統計的デー夕解析入門 実験計画法, 東京図書 株式会社，p.121，2006.

19）国土交通省九州地方整備局山国川河川事務所 : 山国川直 轄河川改修事業報告資料, 2013.

(2014. 9. 30受付) 